\title{
Sustainable harvest of two large predatory Catfish in the Cuiabá river basin, northern Pantanal, Brazil
}

\author{
Penha, JMF* and Mateus, LAF. \\ Laboratório de Ecologia e Manejo de Recursos Pesqueiros, Instituto de Biociências, \\ Universidade Federal de Mato Grosso, CEP 78060-900, Cuiabá, MT, Brazil \\ *e-mail: jpenha@cpd.ufmt.br \\ Received June 8, 2005 - Accepted July 14, 2005 - Distributed February 28, 2007
}

(With 4 figures)

\begin{abstract}
Fishery is an important economic activity in the Pantanal. Among the region's species, the Pimelodidae catfish stands out as an important part of the annual catch. This study assesses the structure, exploitation and stock management of Hemisorubim platyrhynchos and Sorubim cf. lima, the sixth and seventh largest Pimelodidae of the Pantanal. The analysis is based on fish caught by commercial fishing in the Cuiabá river and landed at the "Antônio Moysés Nadaf" Market in the Cuiabá city, Mato Grosso state, Brazil. The findings indicate that commercial fishing activities target several fish cohorts and that usually only individuals above mean length at first maturation are caught. Estimates of the instantaneous mortality coefficient show that the current fishing mortality is low. Simulations of relative yield-perrecruit model demonstrate that the current yield of two species could be greater if the fishery effort were increased, indicating that the stocks are underexploited. However, an increase in current fishery efforts should be viewed with caution, since the stock-recruitment relationship for the species is unknown. The results indicate that the current harvest of two species in the Cuiabá River Basin is sustainable.
\end{abstract}

Keywords: Fisheries management, stock assessment, Pantanal, Hemisorubim platyrhynchos, Sorubim lima.

\section{Pesca sustentável de dois grandes bagres predadores na bacia do Rio Cuiabá, Pantanal norte, Brasil}

\begin{abstract}
Resumo
A pesca é uma importante atividade econômica no Pantanal. Entre as espécies que ocorrem na região, os bagres Pimelodídeos se destacam como uma importante parte da captura anual. Este estudo avalia a estrutura, estado de explotação e o manejo do estoque do Hemisorubim platyrhynchos e Sorubim cf. lima, respectivamente o sexto e o sétimo maiores Pimelodídeos do Pantanal. As análises se baseiam nos peixes capturados no Rio Cuiabá pela pesca e desembarcados no Mercado Municipal "Antônio Moysés Nadaf", na cidade de Cuiabá, Estado do Mato Grosso. Os resultados indicam que a pesca comercial incide sobre várias coortes do estoque e que usualmente somente são capturados indivíduos acima do comprimento médio na primeira maturação. Estimativas do coeficiente instantâneo de mortalidade mostram que a mortalidade por pesca atual é baixa. Simulações do modelo de rendimento relativo por recruta indicam que o rendimento atual das duas espécies poderia aumentar com um aumento no esforço de pesca, indicando que o estoque está subexplotado. Contudo, um aumento no esforço de pesca corrente deve ser visto com cautela, uma vez que a relação entre o estoque e o recrutamento para as espécies é desconhecido. Em síntese, os resultados indicam que o nível atual de captura das duas espécies no Rio Cuiabá é sustentável.
\end{abstract}

Palavras-chave: Manejo da pesca, avaliação de estoques, Pantanal, Hemisorubim platyrhynchos, Sorubim lima.

\section{Introduction}

Freshwater fishing is a major source of income and protein for the riverine populations of most tropical regions (Welcomme, 1992, 2001). Unlike marine catches, the catch of freshwater fish increased from 6.4 million tons/year ${ }^{-1}$ in 1990 to 8 million tons/year ${ }^{-1}$ in 2000 , representing a growth of $37.5 \%$ (FAO, 2002). Most freshwater fishing is carried out on a small scale (small-scale fishing), scattered, and without landing points representative of the regional catch. Moreover, an unknown but considerable part of the catch is sold or consumed locally (Bayley and Petrere, 1989; Welcomme, 2001). Another important characteristic of this type of fishing is its multispecific nature, originating from the coexistence of many fisheries in the same river basin. This set of 
factors makes freshwater fishing particularly difficult to manage, given the difficulties involved in obtaining reliable statistics concerning the catch. Freshwater fishing is therefore especially prone to lead to overfishing of target stocks. Thus, a deeper understanding of its structure and dynamics and the effects of small-scale fishing on freshwater fish stocks are essential prerequisites for the proper definition of sustainable harvest strategies worldwide, without which the fisheries would be condemned to collapse (Pauly et al., 2002).

Sustainable harvest strategies have been adopted historically based on accurate assessment programs. However, the use of good assessment programs has failed to prevent some fisheries from collapsing. This failure is attributable to two sets of related factors: 1) the limitations of assessment models, and 2) the difficulties of ensuring the users' adoption of the management measures resulting from these assessments (Ross, 1997).

There are three major problems relating to the limits of assessment models. The first is the adoption of the maximum sustainable yield as the target. This biological reference point is usually only known after it has been superseded, condemning to collapse the fisheries managed according to this goal (Frank and Leggett, 1994; Kesteven, 1997). The second is that the models adopt premises relating to the shape of the stock-recruitment curve, which, though fundamental, is frequently ignored by users (Clark, 1991; Haddon, 2001). Furthermore, the shape of the stock-recruitment curve is a difficult datum to obtain accurately and is unknown for most of the species exploited. The third problem has to do with the uncertainties involved in estimates of the natural mortality rates (Vetter, 1988), which adds noise to the results of the assessment. To cope with these three limits and increase the reliability of the results of analyses, one must incorporate in the stock assessment protocol a set of strategies that include: a) adoption of more conservative reference points, such as $\mathrm{F}_{0.1}$ (Gulland and Boerema, 1973; Caddy and Mahon, 1995); and b) analysis of the sensitivity of the results to variations in the natural mortality rates (Jensen, 2000).

The second set of factors has to do with actual management and incorporates the complexities and difficulties associated with the use of a common resource. Very often, the ineptitude of the public authorities in dealing with this process has increased the difficulties involved in the sustainability of fishing activity. Fortunately, good results have been achieved when the public authorities share the responsibilities for managing the resource with the users, reaching joint decisions about the best tactics for handling fishing. This strategy, called co-management, has been successfully adopted by many fishing worldwide (Wilson and Nielsen, 2003).

Fishing is an activity practiced from the primordial times of human occupation of the Pantanal, an extensive floodplain that occupies two states in Brazil. Fishing in the region, which is small-scale and scattered along the basin, catches approximately 20 fish species (Catella,
2001, Mateus et al., 2004). Although catches in the past were carried out by a wide variety of different strategies (Ferraz de Lima, 1987; Da Silva and Silva, 1995), legal restrictions currently restrict fishing basically to hookand-line fishing.

The environmental agencies of the two Brazilian states in which the Pantanal wetlands are located - Mato Grosso and Mato Grosso do Sul - have been actively regulating fishing in the region. Today, fishing management consists of the following actions: i) establishment of a minimum capture size; ii) control of fishing efforts and fishing power through the establishment of fishing and fish transportation quotas and a ban on the use of devices; iii) fishing is forbidden during the reproductive period of seasonally migrating fish species; and iv) establishment of reserves in which only the fish-andrelease mode of fishing is permitted. However, there is no common monitoring program aimed at assessing the effectiveness of the various strategies in use. This, allied to clandestine fishing, has made it difficult to compile reliable statistics for the region as a whole. The best fishing information system in the region has been implemented in the portion of the Pantanal wetlands located in the state of Mato Grosso do Sul. Based on this system, what one sees is that most of the fish caught in the southern portion of the Pantanal originates from sports fishing (Catella, 2001). The catch has shown a decline in this portion of the Pantanal. The average landing recorded for the period of 1994 to 1999 was 1,415 tons, 24\% of which was caught by professional fishermen and $76 \%$ by sports fishermen (Catella, 2001).

Studies undertaken in the Pantanal suggest that some stocks are under risk of overfishing. The stock of pacu, Piaractus mesopotamicus, one of the most exhaustively fished species in the Pantanal, is overfished in both the northern (Vaz, 2001) and the southern portion (Catella, 2001; Peixer, 2003). Another species possibly threatened by overfishing is the jaú, Zungaro zungaro, the region's largest catfish (Catella, 2001), the barbado, and the cachara (Mateus, 2003). However, stocks of various other species important for fishing are in a better situation (Catella, 2001; Mateus and Estupiñán, 2002; Mateus, 2003; Mateus and Petrere, 2004).

Hemisorubim platyrhynchos is the sixth and Sorubim cf. lima the seventh largest catfish of the Pantanal (Britski et al., 1999). The two species migrate upriver to spawn during the rainy summer season and the larvae are swept into the lentic and semilotic environments of the flood areas of the major rivers, where they grow. Like others Pimelodidae, they are predators of others fish and are therefore important for the functioning of aquatic ecosystems. Age and growth studies indicate that H. platyrhynchos has a longevity $\left(\mathrm{A}_{0.95}\right)$ of 11.4 years and an asymptotic length $\left(\mathrm{L}_{\infty}\right)$ of $64.0 \mathrm{~cm}$ (Penha et al., 2004 b), while $S$. lima presents an $\mathrm{A}_{0.95}$ of 9.6 years and an $\mathrm{L}_{\infty}$ of $56.0 \mathrm{~cm}$ (Penha et al., 2004a). Adults of both species are caught by commercial fishing, while juveniles are used as ornamental fish. Landing data for the 
southern portion indicates that the total catch of $S$. lima in 1999 was 21 tons while that of $H$. platyrhynchos was 7.8 tons, which, combined, represented about $2.0 \%$ of the total catch during that period (Catella, 2001). No reliable data exist on the catch of these two species in the northern portion of the Pantanal.

Surplus production models indicate that the stocks of these two species are not threatened by overfishing in the southern portion of the Pantanal (Catella, 2001). Nevertheless, it is necessary to deepen the analysis of the effects of the increase in the fishing effort and of management measures, both on the fishing yields and on the stocks' dynamics. Therefore, this study analyzes the current state of exploitation and evaluates the effect of different management alternatives on the stocks of H. platyrhynchos and S. lima in the Cuiabá river basin, northern Pantanal, based on the characterization of the structure in lengths and ages of the fish of the stocks, mortality coefficients and yield per recruit analysis.

\section{Materials and Methods}

\subsection{Study area}

The Pantanal is an extensive floodplain formed by the seasonal overflow of the Paraguay River and its tributaries. It is located in the center of South America, between the parallels $16^{\circ}$ and $22^{\circ} \mathrm{S}$ and the meridians $55^{\circ}$ and $58^{\circ} \mathrm{W}$. This wetland cover an area of approximately 140,000 square kilometers, located mostly in the states of Mato Grosso and Mato Grosso do Sul, in mid-western Brazil. A smaller portion is situated between southeastern Bolivia and northeastern Paraguay. The region is part of a humid and hot climatic zone, with a rainy summer and dry winter (Köppen, 1948). During the wet months, an extensive area of natural grasslands, savannah and forests is flooded by a combination of local rains and overflow from the rivers. The average amplitude of fluctuation of the levels of the rivers in the floodplain varies from 2 to 5 meters (Carvalho, 1986; Da Silva et al., 1998).

All the specimens used in this study originated from commercial fishing in the basin of the Cuiabá River, in the state of Mato Grosso. This river is the largest tributary of the Paraguay River in the northern portion of the Pantanal.

\subsection{Fishery characteristics and sampling procedure}

Small-scale fishermen along the Cuiabá River catch H. platyrhynchos and S. lima and keep them alive for a week. The week's catch is sold on Friday, Saturday and Sunday mornings at the "Antônio Moysés Nadaf" market in the city of Cuiabá, and on Friday, Saturday and Sunday afternoons in the city of Santo Antônio de Leverger. Due to legal inspections, all the fish sold in these two venues come from hook-and-line fishing. Thus, during the first two weeks of each month, from May to October of 2000, all the specimens of the two species landed at the "Antônio Moysés Nadaf" market were measured.
Because of the low catch of these species, it was not possible to obtain randomly selected samples. This procedure enabled us to obtain the fork length measurements (Fl, cm) of 913 H. platyrhynchos and 817 S. lima.

\subsection{Data analysis}

Because the data were right skewed and log transformation did not normalize them, temporal differences in the size of fish caught were analyzed using the KruskalWallis test.

Data of length frequency distribution were converted into age frequency distribution using published von Bertalanffy growth equations. For $H$. platyrhynchos the equation was $\mathrm{Fl}=64\left(1-\mathrm{e}^{-0.222(t+2.149)}\right)$ (Penha et al., 2004b), and for S. lima was $\mathrm{Fl}=56\left(1-\mathrm{e}^{-0.245(\mathrm{t}+2.605)}\right)($ Penha et al., 2004a).

The mean length at which the fish first becomes sexually mature $\left(\mathrm{L}_{\mathrm{m}}, \mathrm{cm}\right)$ was estimated based on its relation with the asymptotic length $\left(\mathrm{L}_{\infty}, \mathrm{cm}\right)$ :

$\log _{10} \mathrm{~L}_{\mathrm{m}}=0.8979 * \log _{10} \mathrm{~L}_{\infty}-0.0782$ (Froese and Binohlan, 2000).

The mean age of the stock's fish, ( $\bar{t}$, years), was estimated based on von Bertalanffy's inverted growth equation: $\overline{\mathrm{t}}=\mathrm{t}_{0}-(1 / \mathrm{k}) * \ln \left(1-\overline{\mathrm{L}} / \mathrm{L}_{\infty}\right)($ Sparre and Venema, 1997), where $L$ is the mean sampled length, $t_{0}$ is the theoretical age at which the length is equal to zero, $\mathrm{k}$ is the growth coefficient, and $\mathrm{L}_{\infty}$ is the asymptotic length.

The total instantaneous mortality coefficient $\left(\mathrm{Z}\right.$, year $\left.{ }^{-1}\right)$ was estimated by two methods: 1) Beverton and Holt's method: $\mathrm{Z}=\mathrm{k} *\left(\mathrm{~L}_{\infty}-\mathrm{L}_{\text {mean }}\right) /\left(\mathrm{L}_{\text {mean }}-\overline{\mathrm{L}} \mathrm{c}\right)$ (Beverton and Holt, 1957), where Lc is the mean length of fish in the first capture, which was assumed to be equal to the peak of the frequency distribution curve (see Figure 1), and $\mathrm{L}_{\text {mean }}$ is the mean length of fish over $\overline{\mathrm{L} c}$ (King, 1995); and 2) Hoenig's method: $\ln (\mathrm{Z})=1.44-0.982 \ln \left(\mathrm{t}_{\max }\right)$ (Hoenig, 1983), where $t_{\max }$ is the maximum age observed in the individuals of the stock, assumed to be equal to the maximum number of growth rings in the spines of the two species. For H. platyrhynchos this value is 7 and for $S$. lima it is 5 (Penha, 2003). The natural instantaneous mortality coefficient $\left(\mathrm{M}\right.$, year $\left.{ }^{-1}\right)$ was estimated using three methods: 1) Pauly's empirical equation (Pauly, 1980): $\ln \mathrm{M}=-0.0152-0.279 * \ln \mathrm{L}_{\infty}+0.6543 * \ln$ $\mathrm{k}+0.4634 * \ln \mathrm{T}$, where $\mathrm{L}_{\infty}$ is the asymptotic length in centimeters, $\mathrm{k}$ is the growth coefficient in year ${ }^{-1}$ and $\mathrm{T}$ is the average annual air temperature $\left(26^{\circ} \mathrm{C}\right)$, assumed to be equal to the water's surface; 2) Hoenig's method (Hoenig, 1983): $\mathrm{M}=-\ln (0.01) / \mathrm{tm}$ and $\mathrm{M}=-\ln (0.05) /$ $\mathrm{tm}$, where tm is the maximum age observed (see Quinn II and Deriso, 1999); and 3) Alverson-Carney's method (Alverson and Carney, 1975): $\mathrm{M}=3 \mathrm{k} / \exp \left(\mathrm{t}^{*} \mathrm{k}\right)-1$, where $\mathrm{k}$ is the growth coefficient and $\mathrm{t} *$ is "critical age"- the age "at which an unfished stock reaches its greatest biomass" (Quinn II and Deriso, 1999), and $\mathrm{t}^{*} \approx 0.38 \mathrm{tm}$ (Alverson and Carney, 1975). However, estimates from Hoenig and Alverson-Carney's method were unrealistic because they were the same or larger than the $\mathrm{Z}$ estimates. Therefore, only M estimates based on Pauly's method were used in the analyses presented here. The fishing mortality coef- 
ficient $\left(\mathrm{F}\right.$, year $\left.{ }^{-1}\right)$ was estimated from the difference between $\mathrm{Z}$ and $\mathrm{M}(\mathrm{F}=\mathrm{Z}-\mathrm{M})$.

The relative yield per recruit ( $\left.Y^{\prime} / \mathrm{R}\right)$ was estimated by the Beverton and Holt method (1964) modified by Pauly and Soriano (1986), using the FISAT software (Gayanilo et al., 1994), according to the following model:

$$
\begin{aligned}
& \mathrm{Y}^{\prime} / \mathrm{R}=\mathrm{EU}^{\mathrm{m} / \mathrm{k}}[1-(3 \mathrm{U} / 1+\mathrm{m})+ \\
& \left.\left(3 \mathrm{U}^{2} / 1+2 \mathrm{~m}\right)-\left(\mathrm{U}^{3} / 1+3 \mathrm{~m}\right)\right]
\end{aligned}
$$

where $\mathrm{m}=(1-\mathrm{E}) /(\mathrm{M} / \mathrm{k})=\mathrm{k} / \mathrm{Z} ; \mathrm{E}=\mathrm{F} / \mathrm{Z}$ (exploitation rate); $\mathrm{U}=1-\left(\mathrm{Lc} / \mathrm{L}_{\infty}\right)$, with $\mathrm{Lc}(\mathrm{cm})$ being the length in the first capture, assumed as the minimum size of capture established by law for the region. This size is $40 \mathrm{~cm}$ for $H$. platyrhynchos and $35 \mathrm{~cm}$ for $S$. lima, expressed in total length (Tl). These values were converted to Fl based on the following expressions: $\mathrm{Fl}=-0.849+0.95 * \mathrm{Tl}$ for $H$. platyrhynchos and $\mathrm{Fl}=0.15+0.954 * \mathrm{Tl}$ for $S$. lima (Penha, 2003), corresponding to a fork length of $37 \mathrm{~cm}$ for $H$. platyrhynchos and $33 \mathrm{~cm}$ for $S$. lima, respectively. The estimates of $\mathrm{L}_{\infty}$ and $\mathrm{k}$ published (see citation above) were used as input parameters to estimate the mortality coefficients and analyze the relative yield per recruit for the species.

We used a sensitivity analysis procedure to deal with the problem of uncertainty involved in the stock assess- ment (Hilborn, 2003). This analysis consisted of investigating the effect of variations in the natural mortality coefficient $(\mathrm{M})$ in the results of relative yield per recruit analysis ( $\left.\mathrm{Y}^{\prime} / \mathrm{R}\right)$.

\section{Results}

The fork length of fish landed at the market varied from 38 to $64 \mathrm{~cm}$, in the case of $H$. platyrhynchos and from 33 to $56 \mathrm{~cm}$ in that of $S$. lima (Figure 1). The mean fork length $(\overline{\mathrm{L}})$ of $H$. platyrhynchos was $44.8 \mathrm{~cm}$ and that of $S$. lima was $41.1 \mathrm{~cm}$. The mean length in the first capture $(\overline{\mathrm{L}} \mathrm{c})$ was estimated at $40 \mathrm{~cm}$ for $H$. platyrhynchos and at $35 \mathrm{~cm}$ for $S$. lima, and the $\mathrm{L}_{\text {mean }}$ was estimated at 45.3 for $H$. platyrhynchos and $41.3 \mathrm{~cm}$ for $S$. lima.

The mean fork length varied over time. In the case of $H$. platyrhynchos, slightly longer lengths were landed in July and August, the region's dry season (Figure 2). S. lima, on the other hand, showed longer mean lengths in June, July and September. The differences were highly significant for both $H$. platyrhynchos $(\mathrm{H}=14.608$, $\mathrm{p}=0.006$, d.f. $=4)$, and S. $\operatorname{lima}(\mathrm{H}=32.373, \mathrm{p}=0.000$, d.f. $=5$ ).

Because the collect effort of specimens was fairly constant and concentrated in the first fortnight of each month,
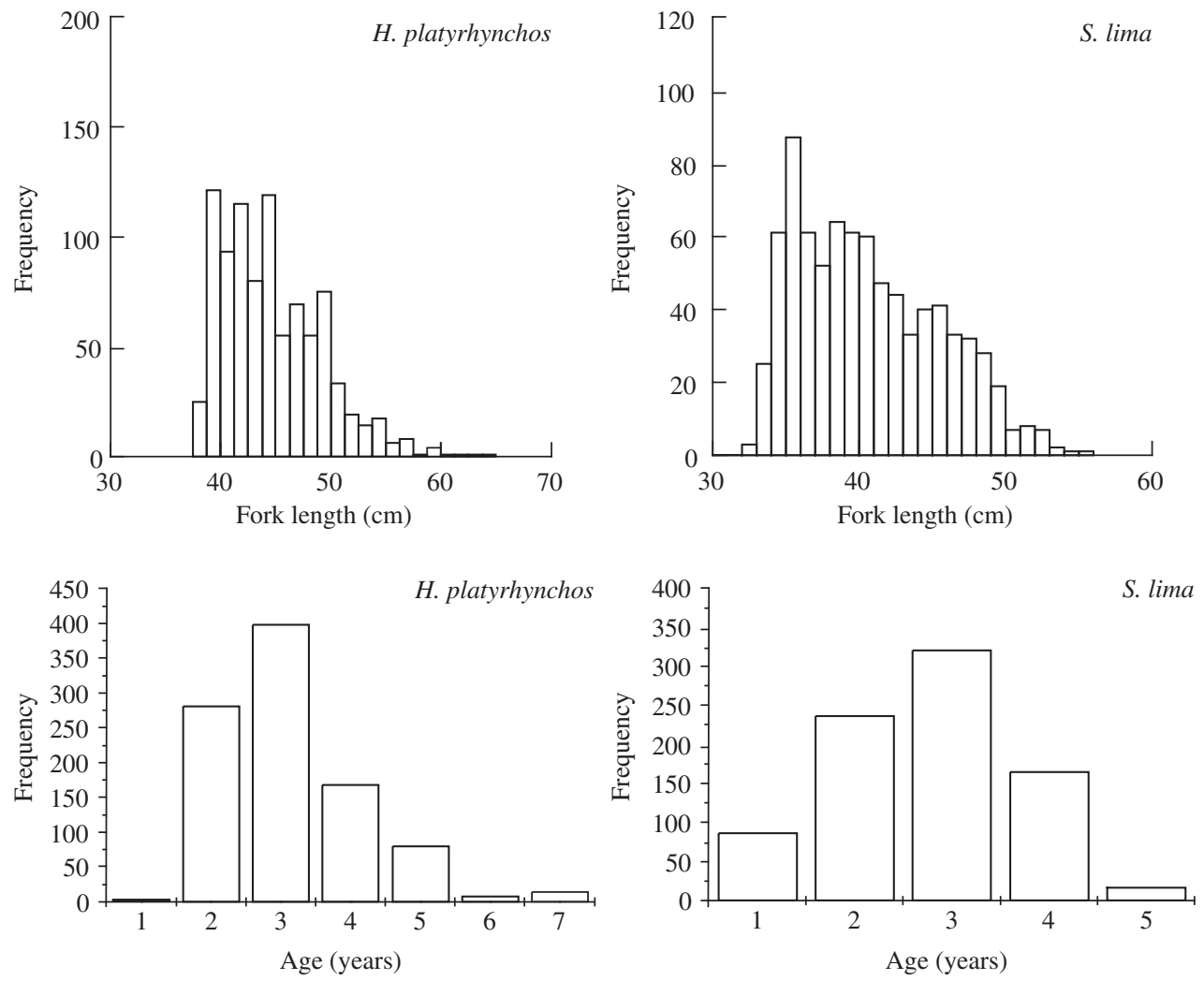

Figure 1. Fork lengths Frequency distribution, and age structure of the sample of H. platyrhynchos and S. lima landed at the "Antônio Moysés Nadaf" Market at Cuiabá city. All the specimens came from the Cuiabá river basin in the Pantanal, Mato Grosso state, Brazil. 
the number of observations could be used as an approximation of the variation in the catch. These data indicate that the catch is stable up to August, increasing sharply in September and October, at the end of the dry season and the beginning of the flooding period (Figure 2).

Individuals of the two species begin being recruited for the fishery in their first year of life. However, the catch of $H$. platyrhynchos was dominated by individuals with ages ranging from the second to fifth years, while that of S. lima was dominated by individuals with ages ranging from the first to the fourth years (Figure 1). The mean age of $H$. platyrhynchos landed at the market was 3.3 years and that of $S$. lima was 2.8 years.

The mean size in the first maturation $\left(\mathrm{L}_{\mathrm{m}}\right)$ of $H$. platyrhynchos was estimated at $35 \mathrm{~cm}$ (Confidence interval $=32.4$ to 37.8$)$ and that of S. lima was estimated at $31 \mathrm{~cm}$ (Confidence interval $=28.8$ to 33.5 ). A comparison of these values with the length frequency distributions (Figure 1) shows that fish were caught after they have reproduced at least once.

The total instantaneous mortality coefficient (Z), estimated by Beverton \& Holt's method, was equal to 0.775 year $^{-1}$ for $H$. platyrhynchos, and 0.563 year $^{-1}$ for S. lima. The value of $\mathrm{Z}$ estimated by Hoenig's method was equal to 0.624 year $^{-1}$ for $H$. platyrhynchos, and 0.869 year $^{-1}$ for $S$. lima. The natural instantaneous mortality coefficient (M) was estimated at 0.52 year $^{-1}$ for $H$. platyrhynchos, and 0.58 year $^{-1}$ for $S$. lima (Table 1 ).

The fishing instantaneous mortality coefficient (F) of $H$. platyrhynchos was estimated at 0.255 year $^{-1}$, assuming Beverton \& Holt's estimate of Z, and at 0.104 year $^{-1}$, for Hoenig's Z. The fishing instantaneous mortality coefficient of $S$. lima was estimated at 0.289 year $^{-1}$ for Hoenig's Z. It was not possible to obtain an estimate of F from Beverton \& Holt's Z for S. lima, since the value of $\mathrm{Z}$ estimated by this method was lower than that of $\mathrm{M}$.

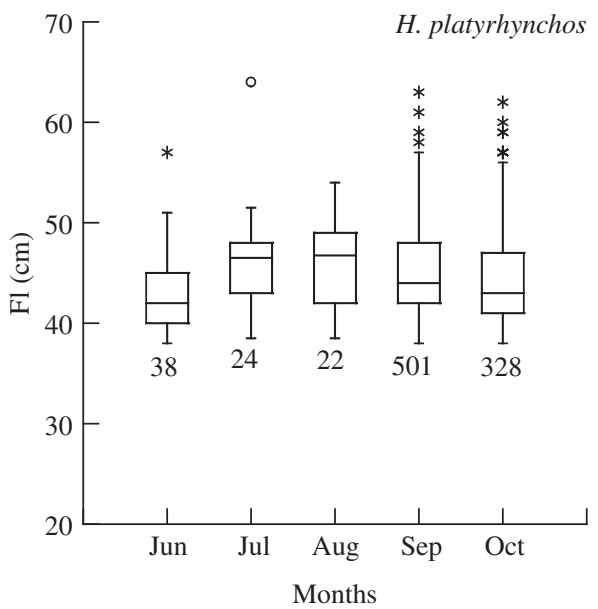

The analysis of the yield per recruit curves as a function of F, Lc and M indicated that the stocks of the two species are not being exploited much by fishing. The parameters used in the simulation are listed in Table 2. An increase in fishing efforts would lead to an increase of yield per recruit. Another conclusion is that, maintaining

Table 1. Populational parameters of mortality (F, Z, M) and the rates of exploitation (E) for $H$. platythynchos and $S$. lima from the Cuiabá river basin in the Pantanal, Mato Grosso state. The numbers in subscript next to the estimates of $\mathrm{Z}$, F and E refer to the model utilized: 1 for Beverton \& Holt's model and 2 for Hoenig's model.

\begin{tabular}{lcc}
\hline Parameters & H. platyrhynchos & S. lima \\
\hline M (year $\left.{ }^{-1}\right)$ & 0.52 & 0.58 \\
Z1 $\left(\right.$ year $\left.^{-1}\right)$ & 0.775 & 0.563 \\
F1 $\left(\right.$ year $\left.^{-1}\right)$ & 0.255 & - \\
E1 & 0.33 & - \\
Z2 $\left(\right.$ year $\left.^{-1}\right)$ & 0.624 & 0.869 \\
F2 $\left(\right.$ year $\left.^{-1}\right)$ & 0.104 & 0.289 \\
E2 & 0.167 & 0.33 \\
\hline
\end{tabular}

Table 2. Values of the estimated parameters used to simulate the effect of variations of the natural mortality coefficient (M) and the minimum capture length (Lc) on the yield-perrecruit.

\begin{tabular}{lll}
\hline Parameters & H. platyrhynchos & \multicolumn{1}{c}{ S. lima } \\
\hline $\mathrm{L}_{\infty}(\mathrm{cm})$ & 64 & 56 \\
$\mathrm{k}\left(\right.$ year $\left.^{-1}\right)$ & 0.222 & 0.245 \\
$\mathrm{Lc}(\mathrm{cm})$ & $27,32,37,42$, & $23,28,33,38$, \\
& and 47 & and 43 \\
M (year-1) & $0.47,0.52$, & $0.53,0.58$, \\
& and 0.57 & and 0.63 \\
\hline
\end{tabular}

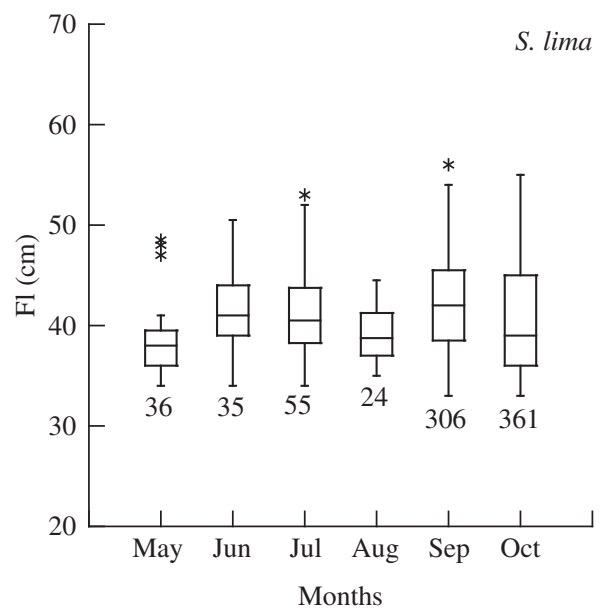

Figure 2. Box-and-Whisker plots related to the fork length of H. platyrhynchos and S. lima landed at the "Antônio Moysés Nadaf" Market at Cuiabá city. All the specimens came from the Cuiabá river basin in the Pantanal, Mato Grosso state. The numbers below the bars indicate the number of observations. 

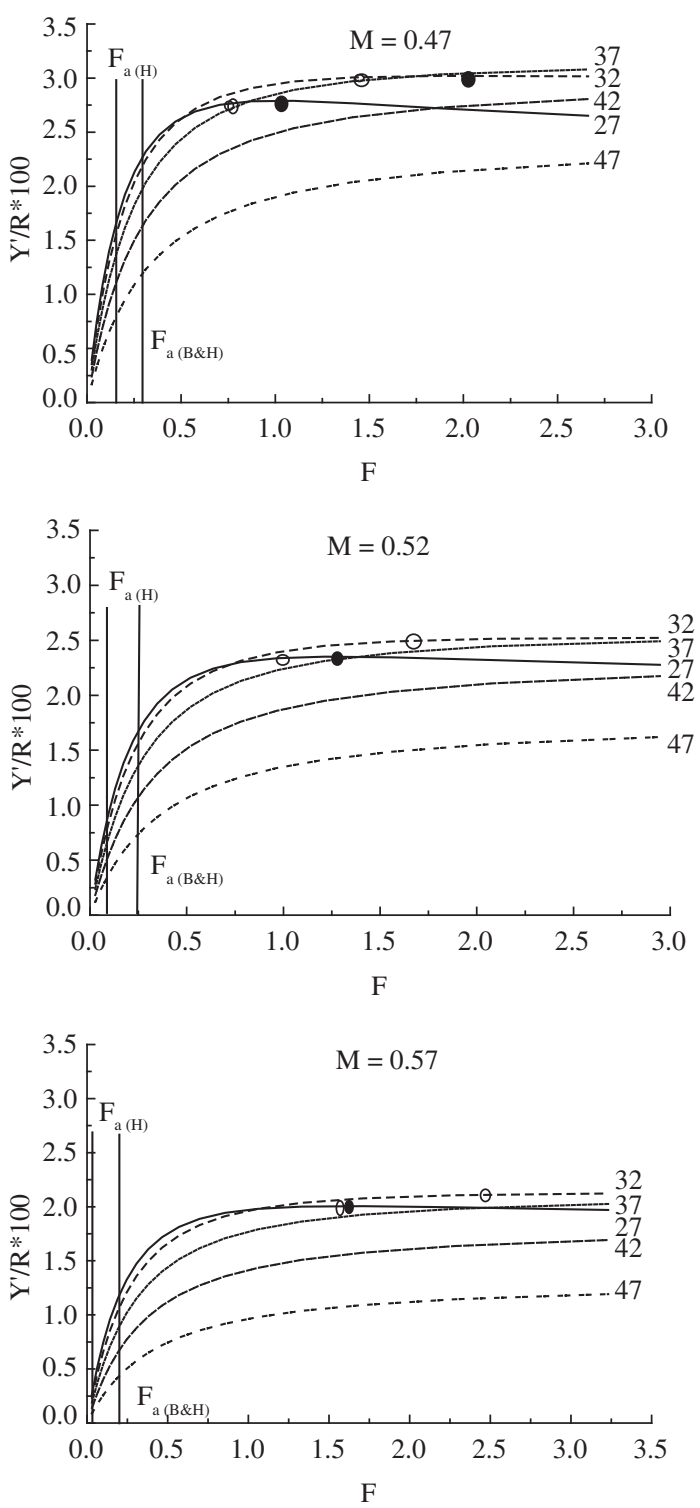

Figure 3. Yield per recruit vs. fishing mortality for H. platythynchos landed at "Antônio Moysés Nadaf" Market at Cuiabá city. All the specimens came from the Cuiabá river basin in the Pantanal, MT. The empty circles indicate $\mathrm{F}_{0.1}$ and the full circles indicate $\mathrm{F}_{\max } . \mathrm{F}_{\mathrm{a}(\mathrm{H})}$ and $\mathrm{F}_{\mathrm{a}(\mathrm{B} \& \mathrm{H})}$ indicate the current fishing mortality coefficients, estimated from Hoenig's and Beverton and Holt's methods, respectively. The numbers in front of the curves represent the Lc.

the current fishing effort, the yield could be increased by reducing the minimum capture size (Figures 3 and 4). However, a measure to increase the minimum capture size would result in a considerable reduction in the stock's yield. These findings are consistent throughout the various levels of the natural mortality analyzed.

The results of the simulation also indicated that an increase in natural mortality $(\mathrm{M})$ due to any factors
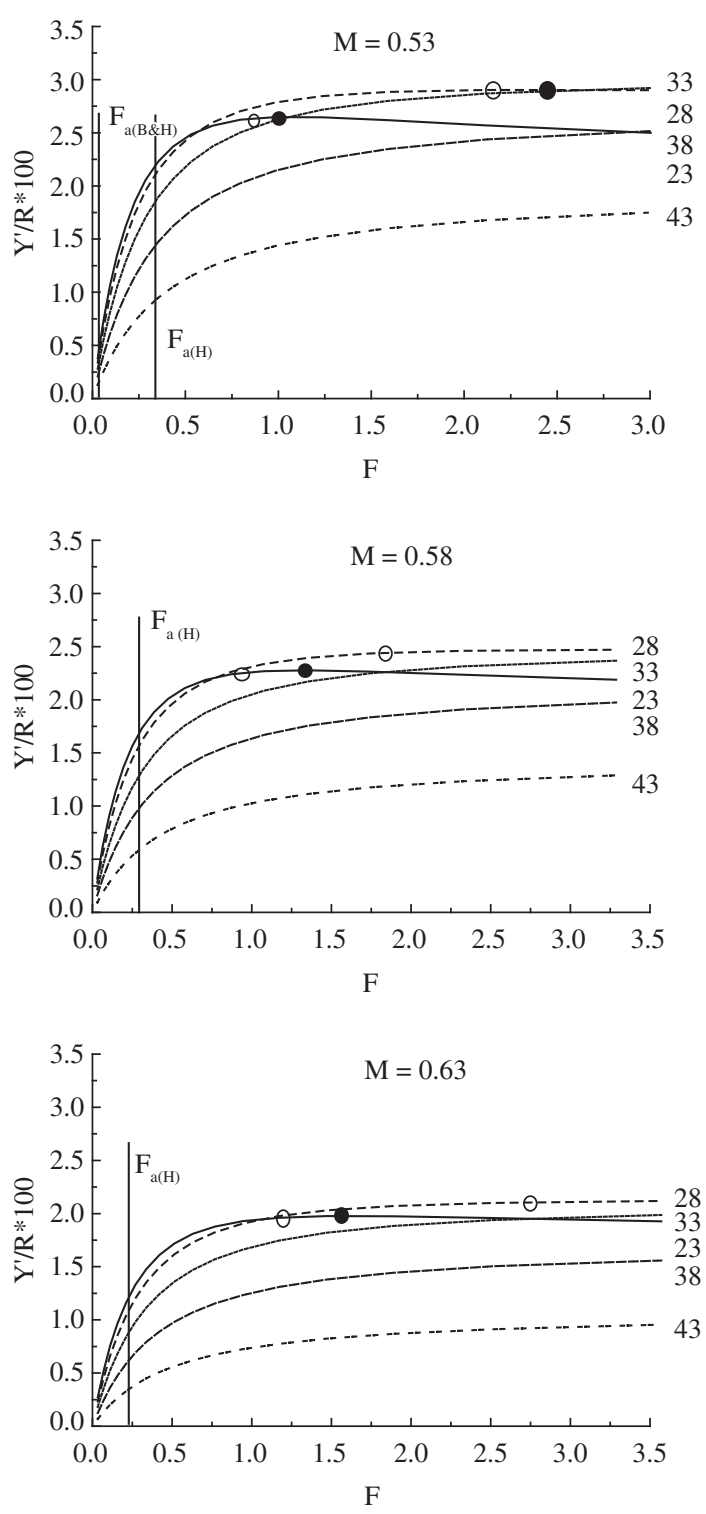

Figure 4. Yield per recruit vs. fishing mortality for S. lima landed at the"Antônio Moysés Nadaf" Market at Cuiabá city. All the specimens came from the Cuiabá river basin in the Pantanal, MT. The empty circles indicate $\mathrm{F}_{01}$ and the full circles indicate $\mathrm{F}_{\max } . \mathrm{F}_{\mathrm{a}(\mathrm{H})}$ and $\mathrm{F}_{\mathrm{a}(\mathrm{B} \& \mathrm{H})}$ indicate the current fishing mortality coefficients, estimated from Hoenig's and Beverton and Holt's methods, respectively. The numbers in front of the curves represent the Lc.

would result in a reduction of the stocks' yields, regardless of the minimum capture size adopted (Lc).

\section{Discussion}

Stock assessment is a necessary condition for fishery management anywhere. However, "because recruitment is not modeled explicitly but is assumed to be constant 
(hence yield-per-recruit) the standard yield-per-recruit analysis does not attend to the issue of whether the fishing rate predicted to produce the maximum yield is likely sustainable" (Haddon, 2001). To deal with this problem and improve the level of confidence in the results, we used an approach that combines length and age distribution analyses, precautionary biological reference points (Caddy and Mahon, 1995; Collie and Gislason, 2001), and sensitivity analyses (Hilborn, 2003) to assess whether the current level of exploitation of the stocks is sustainable. The results of the analyses were convergent and indicated that the $H$. platyrhynchos and S. lima stocks from the Cuiabá river basin, northern Pantanal, have been subject to low levels of exploitation in the last years.

Fishing has targeted a broad range of lengths and ages, but fishing recruitment starts only after the mean size at the first maturation $\left(\mathrm{L}_{\mathrm{m}}\right)$ is reached. This not only ensures that individuals are caught only after contributing to the maintenance of the stock's genetic diversity, but also minimizes the risks associated with the excessive concentration of the effort on larger sized groups, which could remove individuals with the highest growth potential from the stock (Longhurst, 2002). These facts are, in part, a consequence of the minimum capture size established by current legislation, which is longer than the $\mathrm{L}_{\mathrm{m}}$ for both species, and their lower market values when compared to others Pimelodidae, such as Pseudoplatystoma spp. which act to decrease the fishing effort in these species. The minimum capture size adopted to manage the species in the Cuiabá river basin seems to have effectively precluded the threat of growth overfishing for their stocks.

Our simulations of the yield-per-recruit model indicate that an increase in the fishing yield could be attained with a reduction in the minimum capture size of the species. However, two factors suggest that this tactic must not be adopted for the species analyzed here. First, small individuals have low market prices (personal observation of JMFP) and are of little interest for sports fishing. Second, a reduction in minimum capture size would allow for the individuals with the highest growth potential to be removed from the stock before their contribution to the genetic pool is ensured, which could trigger cascade changes in individual growth characteristics, leading to changes in the demography and productivity of the stocks. So, again, the minimum capture size established for the two species in the northern part of the Pantanal, though not based on empirical data, is an adequate compromise between stock conservation and yield potential for fishing.

The results of the simulations of yield per recruit as a function of variations in fishing effort, in natural mortality and in minimum capture size were convergent. Within the range of $\mathrm{M}$ values analyzed, only the curves for lengths below the minimum capture size showed peaks. Yield curves for individuals above the current minimum capture size displayed an asymptotic pattern. This meant it was impossible to determine values for $\mathrm{F}_{0,1}$, the rate at which the inclination of the yield curve per recruit drops to $10 \%$ of its value at the source (Gulland and Boerema,
1973; Caddy and Mahon, 1995), and $\mathrm{F}_{\text {max }}$ for the lengths starting from the minimum capture size.

The current low level of exploitation of the stocks was corroborated by an analysis of the precautionary biological reference points. Even considering a conservative biological reference point, $\mathrm{F}_{0,1}$ (Gulland and Boerema, 1973; Caddy and Mahon, 1995), the current level of exploitation was found to be low.

The strategy of evaluating the stocks based on the combination of approaches adopted in this research appears to be useful when the biological knowledge of the species is limited (Mace, 1994). The three analyses indicate that the current levels of exploitation of the stocks are sustainable. This finding, however, should be evaluated carefully. In river flooding systems, the variability of rainfall affects the intensity and duration of floods, which, in turn, influences the intensity of recruitment (Welcomme and Hagborg, 1977; Gomes and Agostinho, 1997). This characteristic, allied to the unknown of the stock-recruitment relationship for the two species, shortens the temporal validity of the model's predictions (Gulland, 1983; Clark, 1991). Moreover, the growing environmental degradation in the upper reaches of the Paraguay river basin as a whole alters the system's supporting capacity, leading to the depression of stocks, independently of fishing pressure. These considerations add uncertainty regarding the behavior of the stocks in response to a possible increase in the fishing effort. This uncertainty suggests that the best thing to do to ensure that fishing of the two species does not reach a point where there is a risk of overfishing, in the medium and long term, is to adopt the principles of responsible fishing, maintaining management policies currently focusing on two species and ensuring the environmental integrity of the Pantanal.

In addition, to ensure the sustainability of all kinds of fishing in the long term and avoid overfishing of the target stocks, it is necessary for the environmental agencies of the two states to adopt measures to assess the effectiveness of the implemented management actions. Monitoring of the effectiveness of these actions should be a fundamental part of any Management Program. Without it, there is a risk that the effectiveness of good actions is reduced by inefficient actions, or even by detrimental ones. On the other hand, although some measures currently seem right, there is no guarantee that they will work without the commitment of the users. In this sense, sharing the responsibility for the sustainable use of the resource, i.e., adopting co-management, can be useful both, to increase the commitment of users to the conservation and management program and to structure a good system for obtaining fishing statistics and reducing clandestine fishing.

Acknowledgments - The Brazilian Government, through CAPES awarded J.M.F.P. and L.A.F.M. with a PhD grant. We would like to thank Dr. Miguel Petrere Jr. from UNESP, Rio Claro, and Geraldo Barbieri from the Instituto de Pesca, São Paulo, for their support and incentive. The Universidade Federal de Mato Grosso and Pantanal Research Center (CPP) partially funded this research. 


\section{References}

ALVERSON, DL. and CARNEY, MJ., 1975. A graphic review of the growth and decay of population cohorts. J. Cons. Int. Explor. Mer, vol. 36, no. 2, p. 133-143.

BAYLEY, PB. and PETRERE, M., 1989. Amazon fisheries: assessment methods, current status and management options. Can. Spec. Publ. Fish. Aquat. Sci., vol. 106, p. 385-398.

BEVERTON, RJH. and HOLT, SJ., 1957. On the dynamics of exploited fish population. U. K. Min. Agric. Fish., Fish. Invest., Ser. 2. 19.

BEVERTON, RJH. and HOLT, SJ., 1964. Tables of yield functions for fishery management. FAO Fish. Tech. Pap. vol. $38,49 \mathrm{p}$.

BRITSKI, HA., SILIMON, KZS. and LOPES, BS., 1999. Peixes do Pantanal. EMBRAPA-SPI, Brasília e EMBRAPACPAP, Corumbá.

CADDY, JF. and MAHON, R., 1995. References point for fisheries management. FAO Fish. Tech. Pap., vol. 347, 83 p.

CARVALHO, NO., 1986. Hidrologia da bacia do Alto Paraguai. In: I Anais do I Simpósio sobre Recursos Naturais e Sócioeconômicos do Pantanal, EMBRAPA-DDT, Brasília, p. 43-49.

CATElla, AC., 2001. A pesca no Pantanal de Mato Grosso do Sul, Brasil: Descrição, nível de exploração e manejo (1994 - 1999). PhD Thesis. Instituto Nacional de Pesquisas da Amazônia, Manaus.

CLARK, WG., 1991. Groundfish explotation rates based of life history parameters. Can. J. Fish. Aquat. Sci., vol. 48, no. 5, p. 743-750.

COLLIE, JS. and GISLASON, H. 2001. Biological reference points for fish stocks in a multispecies context. Can. J. Fish. Aquat. Sci., vol. 58, no. 11, p. 2167-2176.

DA SILVA, CJ. and SILVA, JAF., 1995. No ritmo das águas do Pantanal. NUPAUB/USP, São Paulo.

DA SILVA, CJ., SOARES, MG., PIEDADE MT. and JUNK, W., 1998. O Pantanal mato-grossense e as várzeas amazônicas: uma comparação da situação ecológica, utilização atual e problemas ambientais. Studies on Human Impacts on Forests and Flood plains in the Tropics, MCT/CNPq, Brasília.

FAO. 2002. Available in http://www.fao.org. Acessed on november, 14. 2002.

FERRAZ DE LIMA, JA., 1987. A tecnologia de pesca no Centro-Oeste do Brasil (Bacia do Alto Paraguai: Pantanal de Mato Grosso). In: Anais do V Congresso Brasileiro de Engenharia de Pesca, Fortaleza, CE, p. 305-323.

FRANK, KT. and LEGGETT, WC., 1994. Fisheries ecology in the context of ecological and evolutionary theory. Ann. Rev. Ecol. Syst., vol. 25, p. 401-422.

FROESE, R. and BINOHLAN, C., 2000. Empirical relationships to estimate asymptotic length, length at first maturity and length at maximum yield per recruit in fishes, with a simple method to evaluate length frequency data. J. Fish Biol., vol. 56, no. 4, p. $758-773$.

GAYANILO Jr., FC., SPARRE, P. and PAULY, D., 1994. The FAO-ICLARM Stock Assessment Tools (FiSAT) User's Guide. FAO Computerized Information Series (Fisheries) 7, 124p.

GOMES LC. and AGOSTINHO, AA., 1997. Influence of the flooding regime on the nutritional state and juvenile recruitment of the curimba, Prochilodus scrofa, Steindachner, in upper Paraná River, Brazil. Fisheries Management and Ecology, vol. 4, p. 263-274.

GULLAND, JA. 1983. Fish stock assessment: a manual of basic methods. FAO/Wiley series on food and agriculture, Chichester.

GULLAND, JA. and BOEREMA, LK., 1973. Scientific advice on catch levels. Fish. Bull., vol. 71, no. 2, p. 325-335.

HADDON, M., 2001. Modeling and quantitative methods in fisheries. Chapman and Hall/CRC, Florida.

HILBORN, R., 2003. The state of the art in stock assessment: where we are and where we are going. Scientia Marina. vol. 67, no. suppl. 1, p. 15-20.

HOENIG, JM., 1983. Empirical use of longevity data to estimate mortality rates. Fish. Bull., vol. 82, no. 4, p. 898-902.

JENSEN, AL., 2000. Harvest reference point for the Beverton and Holt dynamic pool model. Fish. Res., vol. 47, no. 1, p. 93-96.

KESTEVEN, GL. MSY revised. Marine Police, 1997, vol. 21, no. 1, p. $73-82$.

KING, M., 1995. Fisheries biology, assessment andmanagement. Fishing News Books (Blackwell Science), Oxford.

KÖPPEN, GW., 1948. Climatologia. Fundo de Cultura Econômica, México.

LONGHURST, A., 2002. Murphy' law revisited: longevity as a factor in recruitment to fish populations. Fish. Res., vol. 56, no. 2 , p. $125-131$

MACE, PM., 1994. Relationships between common biological reference points used thresholds and targets of fisheries management strategies. Can. J. Fish. Aquat. Sci., vol. 51, no. 1, p. $110-122$.

MATEUS, LAF., 2003. Ecologia da pesca de quatro grandes bagres (Siluriformes: Pimelodidae) na bacia do rio Cuiabá, Pantanal Matogrossense. PhD Thesis. Universidade Estadual Paulista, Rio Claro.

MATEUS, LAF. and ESTUPIÑÁN, GMB., 2002. Fish stock assessment of Piraputanga Brycon microlepis in the Cuiabá river basin, Pantanal of Mato Grosso, Brazil. Braz. J. Biol., vol. 62 , no. 1 , p. $165-170$.

MATEUS, LAF., PENHA, JMF. and PETRERE JR., M., 2004. Fishing resources in the rio Cuiabá basin, Pantanal do Mato Grosso, Brazil. Neotropical Ichthyology, vol. 2, no. 4, p. 217-227.

MATEUS, LAF. and PETRERE Jr., M., 2004. Age, growth and yield per recruit of pintado Pseudoplatystoma coruscans in Cuiabá river basin, Pantanal of Mato Grosso, Brazil. Braz. J. Biol.. vol. 64, no. 2, p. 257-264.

PAULY, D., 1980. On the interrelationships between natural mortality, growth parameters, and mean environmental temperature in 175 fish stocks. Journal du Conseil, vol. 39, no. 2 , p. $175-192$.

PAULY, D., CHRISTENSEN, V., GUÉNETTE, S., PITCHER, TJ., SUMAILA, UR., WALTERS, CJ., WATSON, R. and ZELLER, D., 2002. Towards sustainability in world fisheries. Nature., vol. 418, no. 6898, p. 689-695.

PAULY, D. and SORIANO, ML., 1986. Some pratical extensions to Beverton and Holt's relative yield-per-recruit 
model, In JL. MACLEAN, LB. DIZON and LV. HOSILLO (eds.) The first Asian Fisheries Forum, Asian Fishery Society, Manila, Philippines, p. 491-496.

PEIXER, J., 2003. Seletividade de anzol e rendimento por recruta do pacu, Piaractus mesopotamicus (Holmberg, 1887) no Pantanal de Mato Grosso do Sul. Master Dissertation. Universidade Estadual Paulista, Rio Claro.

PENHA, JMF., 2003. Estrutura e estado de explotação dos estoques do Jurupoca, Hemisorubim platyrhynchos, e do Jurupensém, Sorubim cf. lima, na Bacia do Rio Cuiabá, Pantanal Mato-grossense. PhD Thesis. Universidade Federal de São Carlos, São Carlos.

PENHA, JMF., MATEUS, LAF. and BARBIERI, G., 2004a. Age and growth of the Duckbill Catfish (Sorubim cf. lima) in the Pantanal. Braz. J. Biol., vol. 64, no. 1, p. 125-135.

PENHA, JMF., MATEUS, LAF. and BARBIERI, G., 2004b. Age and growth of the Pothole Shovelnose Catfish (Hemisorubim platyrhynchos) in the Pantanal. Braz. J. Biol., vol. 64, no. 4, p. 833-840.

QUINN, TJ. II and DERISO, RB., 1999. Quantitative Fishery Dynamics. Oxford University Press, New York.
ROSS, MR., 1997. Fisheries conservation and management. Prentice Hall, New Jersey.

SPARRE, P. and VENEMA, SC., 1997. Introdução à avaliação de mananciais de peixes tropicais. Documento Técnico de Pescas da FAO 306/1, Rev. 2. Parte 1: manual, Roma.

VAZ, MM., 2001. Problemas no ajuste da curva de crescimento do pacu, Piaractus mesopotamicus (Holmberg, 1887) (Pices: Characidae), e seu manejo no Pantanal Mato-grossense. $\mathrm{PhD}$ Thesis. Universidade Estadual Paulista, Jaboticabal.

VETTER, E., 1988. Estimation of natural mortality in fish stocks: A review. Fishery Bulletin, vol. 86, no. 1, p. 25-43.

WELCOMME, RL., 1992. Pesca fluvial. Documento Técnico de Pesca da FAO 262, Roma.

WELCOMME, RL., 2001. Inland fisheries: ecology and management. Fishing News Books (FAO/Blackwell Science), Oxford.

WELCOMME, RL. and HAGBORG, D., 1977. Towards a model of a floodplain fish population and its fishery. Env. Biol. Fish., vol. 2, no. 1, p. 7-24.

WILSON, DC. and NIELSEN, JR., 2003. (Eds.). The fisheries co-management experience: accomplishments, challenges and prospects. Kluwer Academic Publishers, Dordrecht. 